\title{
Endogenous Activation of Metabotropic Glutamate Receptors Modulates GABAergic Transmission to Gonadotropin-Releasing Hormone Neurons and Alters Their Firing Rate: A Possible Local Feedback Circuit
}

\author{
Zhiguo $\mathrm{Chu}^{1}$ and Suzanne M. Moenter ${ }^{1,2}$ \\ Departments of ${ }^{1}$ Internal Medicine and ${ }^{2}$ Cell Biology, University of Virginia, Charlottesville, Virginia 22908
}

\begin{abstract}
Gonadotropin-releasing hormone $(\mathrm{GnRH})$ neurons are the primary central regulators of fertility, receiving input from GABAergic afferents via $\mathrm{GABA}_{\mathrm{A}}$ receptors. We tested whether metabotropic glutamate receptors (mGluRs) regulate GABA transmission to GnRH neurons and GnRH neuronal firing pattern. Whole-cell recordings were performed under conditions isolating ionotropic GABA postsynaptic currents (PSCs) in brain slices. The broad-spectrum mGluR agonist 1-aminocyclopentane-1,3-dicarboxylic acid (ACPD) decreased the frequency of $\mathrm{GABA}_{\mathrm{A}}$-mediated spontaneous PSCs in a reversible manner. Amplitude and kinetics were not altered, suggesting that afferent GABA neurons are the primary targets. TTX eliminated the effects of ACPD in most tested neurons. Group II [2-(2,3dicarboxycyclopropyl) glycine] and III (L-AP-4) mGluR agonists mediated this response; a group I agonist (3,5-dihydroxyphenylglycine) was not effective. The broad-spectrum antagonist $\alpha$-methyl-4-carboxyphenylglycine (MCPG) and/or (RS)- $\alpha$-cyclopropyl-4phosphonophenylglycine (CPPG) (group III antagonist) enhanced spontaneous PSC frequency, particularly when initial frequency was low, suggesting that endogenous activation of mGluRs regulates GABA transmission to GnRH neurons. Extracellular recordings were used to evaluate GnRH neuron firing rate within the network. ACPD reduced firing rate, and MCPG plus CPPG had an opposite effect, indicating that mGluRs help control excitability of the GnRH network. GnRH neurons express vesicular glutamate transporters, suggesting they may corelease this transmitter. Simulation of firing activity in a GnRH neuron decreased PSC frequency in that cell, an effect blocked by antagonism of mGluRs but not GnRH receptors. These results demonstrate an inhibition of GABAergic inputs to GnRH neurons by mGluRs via a presynaptic mechanism. Through this mechanism, local glutamate milieu, possibly contributed by GnRH neurons themselves, plays an important role in modulating $\mathrm{GnRH}$ release and the central regulation of fertility.
\end{abstract}

Key words: GnRH; mGluR; GABA; presynaptic; IPSC; firing pattern

\section{Introduction}

Gonadotropin-releasing hormone $(\mathrm{GnRH})$ neurons of the preoptic/hypothalamic area form the final common pathway for the central regulation of reproduction. GnRH neurons receive a substantial portion of their synaptic input from GABA afferents (Leranth et al., 1985; Jansen et al., 2003; Pompolo et al., 2003). Functional GABAergic synaptic transmission to $\mathrm{GnRH}$ neurons via ionotropic $\mathrm{GABA}_{\mathrm{A}}$ receptors varies as a function of reproductive state, and these changes may help drive reproductive cycles and transitions between fertile and infertile conditions (Sim et al., 2000; Sullivan et al., 2003; Sullivan and Moenter, 2004a,b, 2005). Although the consequence of $\mathrm{GABA}_{\mathrm{A}}$ receptor activation in

Received Jan. 10, 2005; revised April 29, 2005; accepted May 8, 2005.

This work was supported by National Institutes of Health Grant HD34860. A portion of this work was presented in abstract form at the 2004 Annual Meeting of The Endocrine Society. We thank Susan Xu for excellent technical assistance, Michael Johnson of the Department of Pharmacology for statistical advice, and Pei-San Tsai, Catherine Christian, Talent Shevchenko, Changqing $\mathrm{Xu}$, and Jin Zhai for useful editorial comments.

Correspondence should be addressed to Suzanne M. Moenter, Department of Internal Medicine, University of Virginia, Charlottesville, VA 22908. E-mail: Moenter@virginia.edu.

DOI:10.1523/JNEUROSCI.0913-05.2005

Copyright $\odot 2005$ Society for Neuroscience $\quad$ 0270-6474/05/255740-10\$15.00/0
GnRH neurons is controversial (Sim et al., 2000; DeFazio et al., 2002; Han et al., 2002, 2004; Sullivan et al., 2003; Moenter et al., 2004; Sullivan and Moenter, 2004a, 2005), mechanisms regulating this key synaptic input are poised to play a major role in the central regulation of fertility (Jarry et al., 1988; Kasuya et al., 1999; Bilger et al., 2001).

Considerable evidence supports a role for metabotropic glutamate receptors (mGluRs) as a regulator of synaptic transmission (Nakanishi, 1992, 1994; Conn and Pin, 1997). mGluRs are G-protein-coupled receptors that can be divided into three main groups depending on sequence homology, signal transduction mechanisms, and pharmacology. Activation of mGluRs modulates a number of synaptic and membrane properties, producing both excitatory and inhibitory effects in many brain regions (Schoepp and Conn, 1993; Anwyl, 1999) including the hypothalamus (Schrader and Tasker, 1997; van den Pol et al., 1998). mGluRs can affect action potential generation in the somatodendritic region, fine tune synaptic transmission at presynaptic terminals, and/or alter the responsiveness of the postsynaptic cell. In the hypothalamus, these receptors are most densely expressed 
A

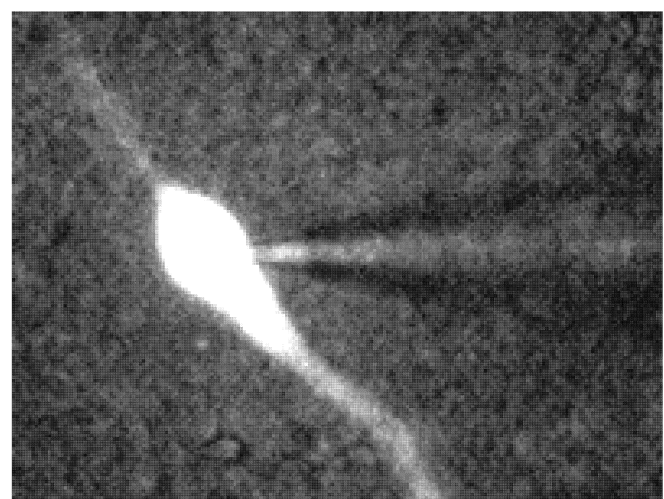

C control
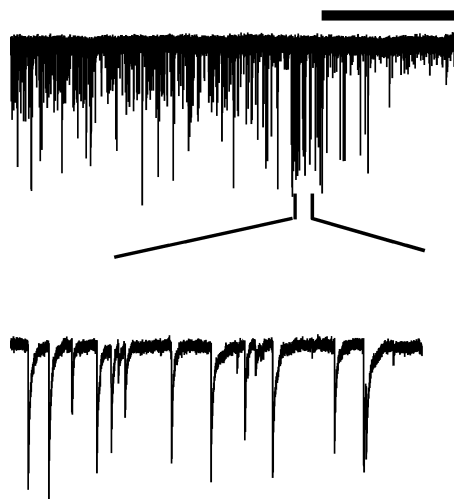

$100 \mathrm{pA}$

$2 \mathrm{sec}$
B

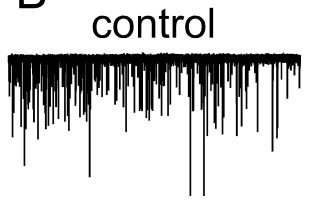

bic

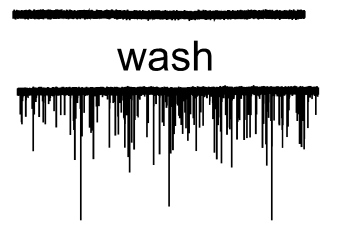

$200 \mathrm{pA}$

$20 \mathrm{sec}$

wash

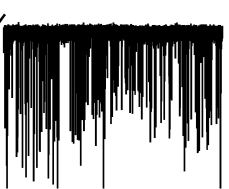

4

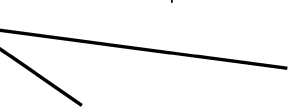

$100 \mathrm{pA}$

Figure 1. Spontaneous GABAergic PSC frequency in GnRH neurons is decreased by ACPD. $A$, Combined bright-field and fluorescent image of a GFP-identified GnRH neuron in the whole-cell configuration. $B, C$, Whole-cell voltage-clamp recording of sPSCS from a GnRH neuron in sagittal brain slices using near-symmetrical chloride at a holding potential of $-60 \mathrm{mV}$. APV $(20 \mu \mathrm{M})$ and CNQX (20 $\mu \mathrm{m})$ were used to block ionotropic glutamate receptor-mediated EPSCS. B, Representative trace of spontaneous PSCs recorded from a GnRH neuron showing reversible elimination of all sPSC events by the $G A B A_{A}$ receptor antagonist bicuculline (bic). C, ACPD (50 $\mu \mathrm{m}$; bar) reduced PSC frequency. Portions of the trace are expanded below for clarity. wash, Washout.

in areas associated with neuroendocrine regulation (Meeker et al., 1994).

Whether mGluRs play a role in central reproductive function through modulation of GnRH neurons is unknown. mGluRs have been implicated in the regulation of preoptic/hypothalamic astrocytic function, which is, in turn, likely important to the activity of GnRH neurons (Dziedzic et al., 2003). Work using cultured transformed GnRH neuronal cell lines has shown mGluR agonists can activate GnRH release (Sortino et al., 1996). To our knowledge, this has not been explored in native GnRH neurons nor are there reports on direct regulation of GnRH neurons or their upstream regulators by mGluR agonists or antagonists. A recent report that $\mathrm{GnRH}$ neurons express vesicular glutamate transporter 2 (VGLUT2) and are thus likely glutamatergic (Hrabovszky et al., 2004) provides additional possible mechanisms for local network feedback control of synaptic communication to these neurons via a glutamate-mGluR mechanism.

We performed a series of studies to examine the modulatory role of mGluRs on $\mathrm{GABA}_{\mathrm{A}}$ receptor-mediated postsynaptic currents (PSCs) in GnRH neurons and their effects on neuronal firing pattern of these cells. Our results suggest endogenous mGluRs play a role in regulating GABAergic neurons presynaptic to GnRH neurons and thereby the function of the GnRH neuronal network and that GnRH neurons may be one source of the glutamate activating these receptors.

\section{Materials and Methods}

Animals and slice preparation. Adult (2-3 month old) female mice expressing enhanced green fluorescent protein (GFP; Clontech, Palo Alto, CA) under the control of the GnRH promoter were used to facilitate identification of GnRH neurons (Suter et al., 2000). Mice were maintained under a 14/10 h light/dark photoperiod with Harlan (Indianapolis, IN) 2916 chow and water available ad libitum. To avoid the confounding effect of changes in ovarian hormone during the estrous cycle, mice were ovariectomized under Metofane (Janssen Pharmaceuticals, North York, Ontario, Canada) or isoflurane (Burns Veterinary Supply, Westbury, NY) anesthesia 5-9 d before experimentation; time after gonadectomy did not affect results. The long-acting local anesthetic bupivicaine $(0.25 \%$; Abbott Labs, North Chicago, IL) was applied to surgical sites to minimize any distress of the procedure. The University of Virginia Institutional Animal Care and Use Committee approved all procedures.

All chemicals were purchased from Sigma (St. Louis, MO) unless noted. All solutions were bubbled with $95 \% \mathrm{O}_{2}$ and $5 \% \mathrm{CO}_{2}$ to maintain $\mathrm{pH}$ and oxygenation for at least 15 min before use and throughout experiments. Brain slices were prepared with slight modifications of previously described procedures (Nunemaker et al., 2002, 2003a). In brief, mice were decapitated, and brains were quickly removed and immersed immediately for 30-60 s in ice-cold sucrose buffer containing the following (in $\mathrm{mm}$ ): 250 sucrose, $3.5 \mathrm{KCl}, 26 \mathrm{NaHCO}_{3}, 10$ glucose, $1.25 \mathrm{NaHPO}_{4}, 1.2 \mathrm{MgSO}_{4}$, and $3.8 \mathrm{MgCl}_{2}$. Sagittal brain slices $(300 \mu \mathrm{M})$ through the preoptic area (POA) and hypothalamus were cut using a Vibratome 1000 or Vibratome 3000 (Technical Products International, St. Louis, MO). Slices were transferred immediately into a holding chamber and incubated at $32-34^{\circ} \mathrm{C}$ for a $30 \mathrm{~min}$ recovery period in a mixture of $50 \%$ sucrose saline and $50 \%$ normal saline containing the following (in mM): $125 \mathrm{NaCl}, 3.5 \mathrm{KCl}, 26 \mathrm{NaHCO}_{3}$, $1.25 \mathrm{NaH}_{2} \mathrm{PO}_{4}, 2.5 \mathrm{CaCl}_{2}, 1.2 \mathrm{MgSO}_{4}$, and 10 D-glucose, $\mathrm{pH}$ 7.4. Slices were then transferred to $100 \%$ normal saline and maintained at room temperature $\left(\sim 21-23^{\circ} \mathrm{C}\right)$ until study $(30 \mathrm{~min}$ to $8 \mathrm{~h}$ ). Slices were transferred to a recording chamber mounted on the stage of an upright microscope (Olympus BX50WI; Odelco, Dulles, VA). The chamber was perfused continuously with normal saline at a rate of $5 \mathrm{ml} / \mathrm{min}$ at $32^{\circ} \mathrm{C}$, and slices were stabilized in the chamber for at least $5 \mathrm{~min}$ before recording.

Recordings. Pipettes (2-4 M $\Omega$ ) were pulled from borosilicate glass capillaries (outer diameter, $1.65 \mathrm{~mm}$; inner diameter, $1.12 \mathrm{~mm}$; World Precision Instruments, Sarasota, FL) using a Narishige model pp-830 puller (Pacer Scientific, Los Angeles, CA). Recordings were made in voltage-clamp mode of an EPC-8 or using one headstage of an EPC-10 dual amplifier (HEKA, Mahone Bay, Nova Scotia, Canada). Experiments were performed using PulseControl XOP (Instrutech, Port Washington, NY) or PatchMaster (HEKA). Signals were stored on a G4 Macintosh computer (Apple Computer, Cupertino, CA) using Igor Pro software (WaveMetrics, Lake Oswego, OR). Voltage signals were low-pass filtered at $5 \mathrm{kHz}$ (whole-cell) or $10 \mathrm{kHz}$ (extracellular) and digitized at 16-bit resolution (ITC-18 acquisition interface; Instrutech). During whole-cell recordings, input resistance $\left(R_{\mathrm{in}}\right)$, series resistance $\left(R_{\mathrm{s}}\right)$, and membrane capacitance $\left(C_{\mathrm{m}}\right)$ were continually measured. Only recordings with $R_{\text {in }}$ $>500 \mathrm{M} \Omega, R_{\mathrm{s}}<20 \mathrm{M} \Omega$, and stable $C_{\mathrm{m}}$ were used for analysis. Data were further examined to make sure changes in $R_{\text {in }}$ or $R_{\mathrm{s}}$ within acceptable limits did not influence results. For whole-cell recordings, a calculated 
liquid junction potential error of $0.3 \mathrm{mV}$ was not corrected (Barry, 1994). Neurobiotin or biocytin $(0.5 \%)$ was included in some cells for morphological study.

GnRH-GFP neurons from the POA and ventral hypothalamus were identified by brief illumination at $470 \mathrm{~nm}$. For whole-cell recording of $\mathrm{GABA}_{\mathrm{A}}$ receptor-mediated PSCs, pipettes were filled with high-chloride solution containing the following (in $\mathrm{mM}$ ): $140 \mathrm{KCl}, 10 \mathrm{HEPES}, 5 \mathrm{EGTA}$, 4.0 MgATP, $0.4 \mathrm{NaGTP}$, and 1.0 $\mathrm{CaCl}_{2}$, pH 7.3, $290 \mathrm{mOsm}$. To isolate GABAergic currents, ionotropic glutamatergic currents were blocked with a combination of $20 \mu \mathrm{M}$ 6-cyano-7-nitroquinoxaline-2,3-dione (CNQX) and $20 \mu \mathrm{M} \mathrm{D}(-)$-amino-5-phosphonovaleric acid (D-APV). Under these conditions, $\mathrm{GABA}_{\mathrm{A}}$ receptor-mediated PSCs recorded at $-60 \mathrm{mV}$ are inward currents. After a control period, metabotropic glutamate receptor blockers or agonists (all from Tocris Cookson, Ellisville, MO) or tetrodotoxin (TTX; $0.5 \mu \mathrm{M}$; Calbiochem, La Jolla, CA) were applied as detailed in Results, with each neuron serving as its own control. For extracellular recording, pipettes were filled with HEPES solution containing the following (in mM): $150 \mathrm{NaCl}, 10$ HEPES, 10 glucose, 2.5 $\mathrm{CaCl}_{2}, 1.3 \mathrm{Mg} \mathrm{Cl}_{2}$, and $3.5 \mathrm{KCl}$. Loose seals of $10-30 \mathrm{M} \Omega$ were formed, and downward deflecting action currents were recorded in voltageclamp mode at $0 \mathrm{mV}$. Treatments were applied as detailed in Results, with each neuron again serving as its own control.

Analysis. PSCs were analyzed off-line using software developed in Igor Pro (Sullivan et al., 2003) and by Minianalysis (Synaptosoft, Decatur, GA). Spontaneous events were detected automatically and confirmed by eye. Detection errors were corrected manually. Averaged PSC waveforms were generated for each $120 \mathrm{~s}$ recording time after aligning PSCs on rising phase. Interevent intervals, peak amplitude, rate of rise time, and 10$90 \%$ decay time were measured. Data generated were transferred to a spreadsheet (Excel; Microsoft, Redmond, WA) or Instat (GraphPad Software, San Diego, CA) for additional statistical analysis. Cumulative probability distributions were made as described previously (Sullivan and Moenter, 2003). Events during extracellular recordings were detected using custom software in Igor Pro (Nunemaker et al., 2002).

All values are expressed as mean \pm SEM. Statistical comparisons were made using paired parametric or nonparametric tests as dictated by data distribution. Specific tests are indicated in Results. $p<0.05$ was considered significant.

\section{Results}

A total of 216 GFP-identified GnRH neurons (Fig. 1A) from 109 animals were recorded in POA and ventral hypothalamus. No difference attributable to location or the $\mathrm{GnRH}$ neuron or time in chamber was observed.

\section{Activation of mGluRs reduces spontaneous GABAergic PSC frequency in GnRH neurons}

To determine whether metabotropic glutamate receptors play a role in regulating GABAergic communication with GnRH neurons, whole-cell recordings were performed on GFP-identified neurons under conditions to enhance and isolate GABAergic PSCs. At a holding potential of $-60 \mathrm{mV}$, downward deflecting currents were completely blocked by the $\mathrm{GABA}_{\mathrm{A}}$ antagonist bicuculline $(n=4 ; 20 \mu \mathrm{M})$ (Fig. $1 B)$ or picrotoxin $(100 \mu \mathrm{M} ; n=3)$ (data not shown), confirming that they were mediated by $\mathrm{GABA}_{\mathrm{A}}$ receptors.

As illustrated in Figure $1 C$, the broad-spectrum mGluR agonist 1-aminocyclopentane-1,3-dicarboxylic acid (ACPD) markedly suppressed spontaneous GABAergic PSCs (sPSCs) in GnRH neurons. This effect was dose dependent (30-100 $\mu \mathrm{M})$ and reversible after washout. ACPD $(100 \mu \mathrm{M})$ completely abolished sPSCs in three of six cells tested; in the remaining three cells, sPSC interevent interval was markedly reduced. Because sPSCs were eliminated by $100 \mu \mathrm{M}$ ACPD in one-half of cells, kinetic studies were compromised. All additional experiments were thus performed with $50 \mu \mathrm{M}$ ACPD. At this concentration, ACPD reduced
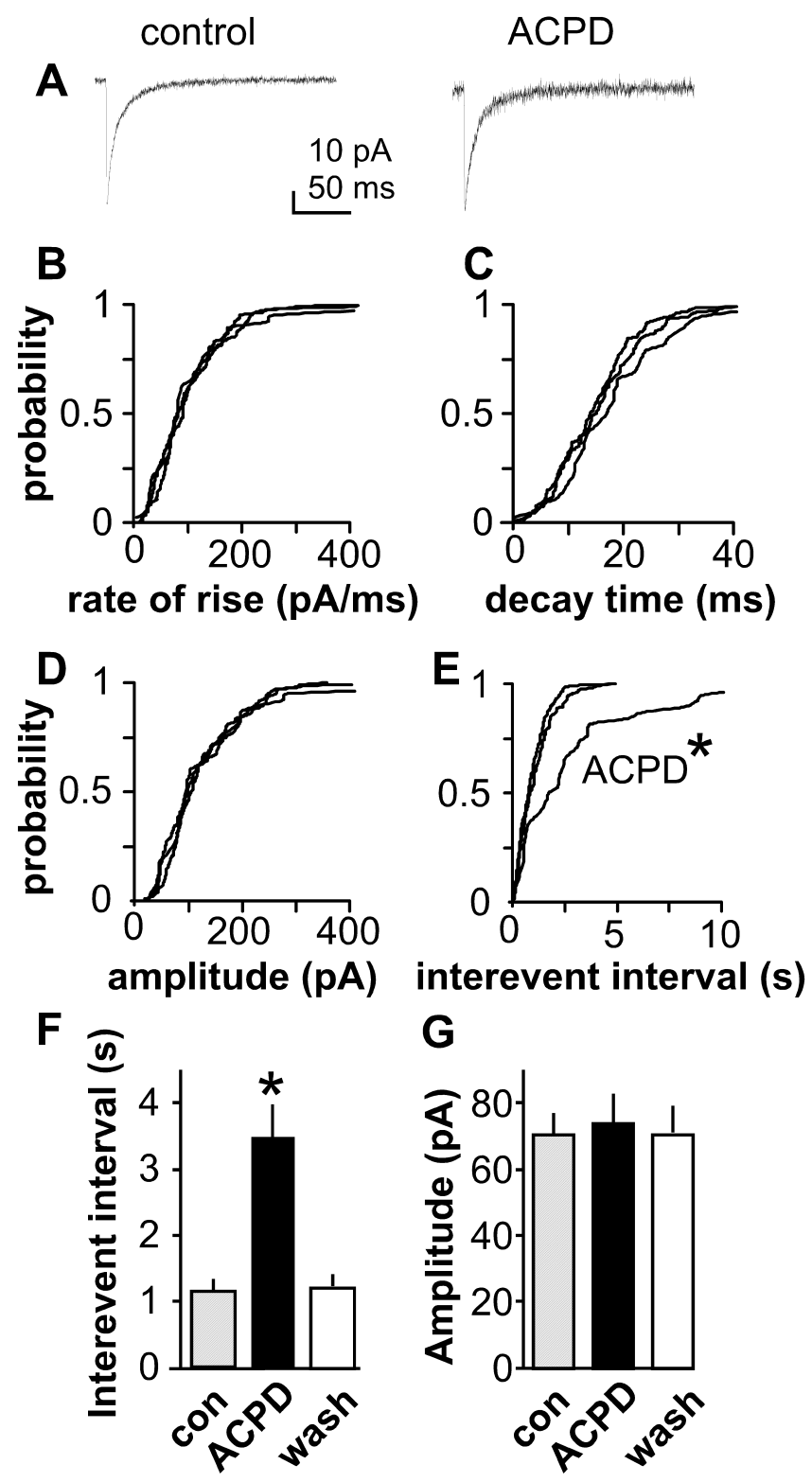

Figure 2. $A C P D$ increased interval but did not affect amplitude or kinetics of spontaneous PSCS. $A$, Average of spontaneous PSCs recorded over 2 min illustrating the average waveform under control (left) and ACPD (right) conditions. $\boldsymbol{B}-\boldsymbol{E}$, Probability distributions of rate of rise, decay time, amplitude, and interevent interval, respectively, from a typical cell during the control period, ACPD treatment, and drug washout. $\boldsymbol{F}, \mathbf{G}$, Mean \pm SEM interevent interval and amplitude, respectively; $n=13$. ${ }^{*} p<0.05$ in $\boldsymbol{E}$; $p<0.001$ in $\boldsymbol{F}$. con, Control; wash, washout.

sPSC frequency in 11 of 13 cells tested in the initial experiment (Fig. 1C) and in $\sim 85 \%$ of GnRH neurons tested with mGluR agonists in various parts of the following studies. This is reflected by an increase in interevent interval $(1103 \pm 185$ vs $3108 \pm 516$ ms; $n=13 ; p<0.001$; paired $t$ test).

To help differentiate between presynaptic and postsynaptic locations for the mGluRs that mediate these effects, the amplitude and kinetics of sPSCs before and during application of ACPD were studied. Amplitude, decay time, and rate of rise were not affected by $50 \mu \mathrm{M}$ ACPD (Fig. 2). This is illustrated by the similarity in average PSC waveform before and during ACPD treatment (Fig. $2 \mathrm{~A}$ ), by the overlap in distribution plots of values for these parameters during the control, ACPD treatment, and washout periods (Fig. $2 B-D$ ), and by the summary bar graph of 
A
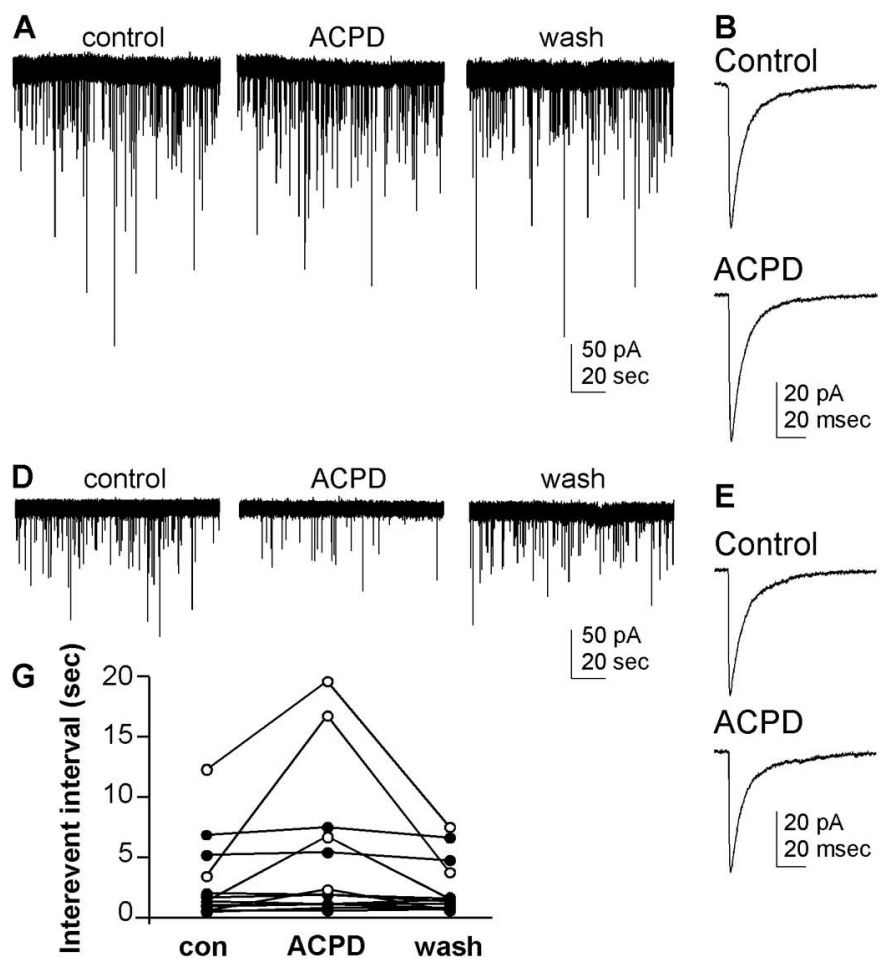

$50 \mathrm{pA}$
$20 \mathrm{sec}$

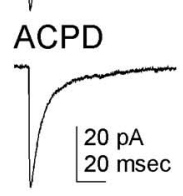

Figure 3. Effects of ACPD on mPSCs. Recordings were obtained in the presence of $0.5 \mu \mathrm{M}$ TTX.A-C, Data from the majority of neurons in which TTX blocked the effects of ACPD. $\boldsymbol{A}$, Representative examples of mPSCs before (left), during (middle), and after (right) application of $50 \mu \mathrm{M}$ ACPD. $\boldsymbol{B}$, Average of miniature PSCs recorded over $2 \mathrm{~min}$ illustrating the average waveform during control (top) and ACPD (bottom). $\boldsymbol{C}$, Mean \pm SEM percentage change in interevent interval. $\boldsymbol{D}-\boldsymbol{F}$, Data from the minority of neurons in which TTX did not block the effects of ACPD. Descriptions are as in $\boldsymbol{A}-\boldsymbol{C}$, respectively. $\mathbf{G}$, Data from each individual cell showing a lack of effect of ACPD in most cells (filled symbols) and a clear increase in interval in four cells (open symbols). The calibration for $\boldsymbol{A}$ and $\boldsymbol{D}$ is the same, as is the calibration for $\boldsymbol{B}$ and $\boldsymbol{E}$. con, Control; wash, washout.

mean amplitude values (Fig. $2 G$ ). Because amplitude and decay time may be mediated at the postsynaptic level, these data imply a lack of effect on the postsynaptic $\mathrm{GnRH}$ neuron at least with regard to its response to activation of $\mathrm{GABA}_{\mathrm{A}}$ receptors. In contrast, interevent interval (Fig. $2 E, F$ ) was markedly increased by ACPD ( $p<0.05$; Komolgorov-Smirnov test). The difference was evident over most of the interevent interval distribution (note deviation of ACPD trace at $\sim 0.35$ on the ordinate of Fig. $2 E)$. This deviation point may reflect a heterogeneous phenotype of GABAergic afferents with regard to mGluR activation but is a consistent observation among cells.

To further explore the possible presynaptic mechanisms by which mGluRs reduce frequency of sPSCs, the effects of ACPD were evaluated in the presence of TTX $(0.5 \mu \mathrm{M})$ to block action potential-dependent effects. PSCs recorded in the presence of tetrodotoxin are independent of propagated action potentials and are referred to as miniature PSCs (mPSCs). In the presence of TTX, most cells (9 of 13) no longer exhibited a reduction in mPSC frequency after ACPD treatment (Fig. $3 A-C$, filled symbols in $G)$, suggesting that mGluR activation in the somatodendritic region of the presynaptic GABA neuron reduces the ability to generate action potentials. In contrast, in a few cells ( 4 of 13), ACPD increased mPSC interevent interval by more than twofold (Fig. 3D-F, open symbols in $G$ ). This suggests that in some GABAergic afferents, mGluRs located in the terminals can alter mechanisms that contribute to action potentialindependent, random thermodynamic release of vesicles. There was no change in any cell in the amplitude of mPSCs after treatment with ACPD (Fig. $3 B, E$ ), consistent with the above obser-
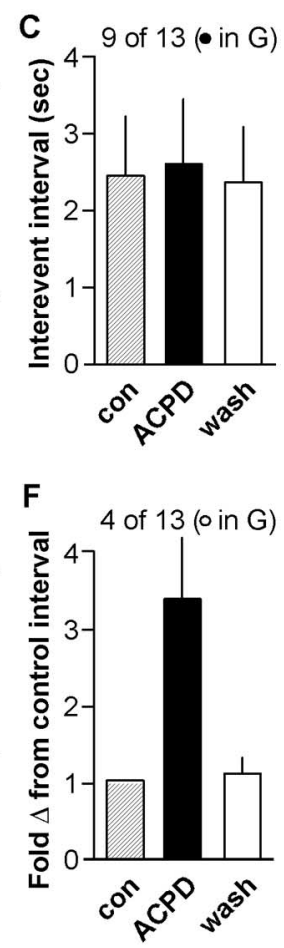

vation for sPSCs and suggesting that the primary actions of $\mathrm{mGluR}$ in altering GABAergic transmission to GnRH neurons are at the presynaptic cell.

\section{Group II and III receptors mediate effects of mGluRs on GABA PSCs in GnRH neurons}

To further characterize the effects of mGluR on GABA PSCs, the effects of agonists specific for different subtypes of mGluR receptors were examined. The group I agonist 3,5-dihydroxyphenylglycine (DHPG) $(50 \mu \mathrm{M} ; n=9)$ had no effect on any property of GABA PSCs in GnRH neurons $(p>0.5)$ (Fig. $4 A, B, E)$. Because group I receptors are typically located postsynaptically, this is consistent with the lack of effect of mGluRs on PSC amplitude and kinetics in GnRH neurons. In contrast to the lack of effect of group I agonists, both group II [2-(2,3dicarboxycyclopropyl) glycine (DCG-IV); $1 \mu \mathrm{M}$ ] (Fig. 4C,E) and group III (L-AP-4; $50 \mu \mathrm{M}$ ) (Fig. 4D,E) agonists reduced the frequency of sPSCs in a subset of GnRH neurons. Specifically, group II agonists reduced frequency in all cells $(n=20 ; p<$ $0.001)$, and group III agonists reduced frequency in 9 of 13 cells $(n=13 ; p<0.05)$. Again, there was no effect of these agonists on kinetics or amplitude (data not shown), and no cell tested responded only to the group III agonist

To determine whether GnRH neurons receive GABA drive from different functional subpopulations of GABA afferents that are distinguished by mGluR subtype, group II and III agonists were applied in sequence during recording of the same GnRH neuron $(n=12)$ (Fig. 5). In 6 of 12 cells, both group II and III agonists reduced frequency; in 4 of 12 cells, only group II agonists were effective; and in 2 of 12 cells, there was no response. Order of agonist application had no effect (six cells, group II first; six cells, group III first). This suggests GABA afferents of GnRH neurons primarily express group II $\mathrm{mGluR}$ and that a subset also expresses group III receptors.

\section{Endogenous activation of mGluRs affects GABA PSCs}

The above studies clearly demonstrate an effect of exogenously applied activators of mGluR on GABAergic PSCs, but a more biologically interesting question is whether or not endogenous glutamate alters the activity of these afferents. To test this, the effects of the broad-spectrum mGluR antagonist $\alpha$-methyl-4carboxyphenylglycine (MCPG; $1 \mathrm{mM}$ ) on sPSCs were tested (Fig. 6). At this dose, MCPG is less effective at blocking group III mGluRs. To ensure effective blockade of this receptor subtype, $(R S)-\alpha$ cyclopropyl-4-phosphonophenylglycine (CPPG; $200 \mu \mathrm{M})$, a specific group III antagonist, was added with MCPG in some cells; data were similar, and only data from MCPG alone are shown $(n=19$ cells, MCPG alone; $n=11$ cells, MCPG plus CPPG). The overall effect of MCPG alone or in combination with CPPG was to increase the frequency of GABAergic sPSCs, reducing interevent interval $(p<$ 0.01; paired $t$ test) (Fig. 6C,D). It is of interest, however, that the magnitude of the effect of mGluR antagonism depended on the con- 

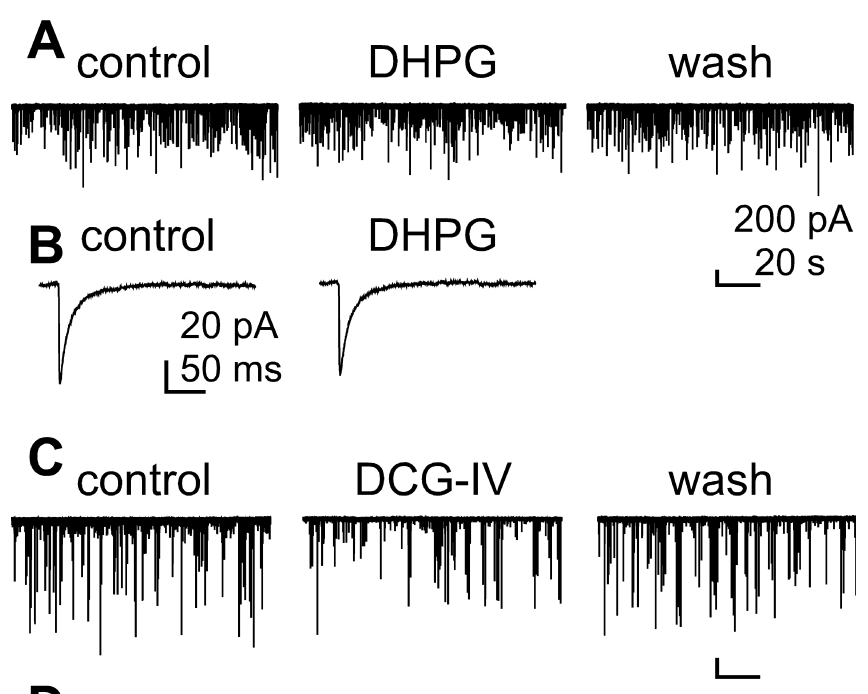

D control
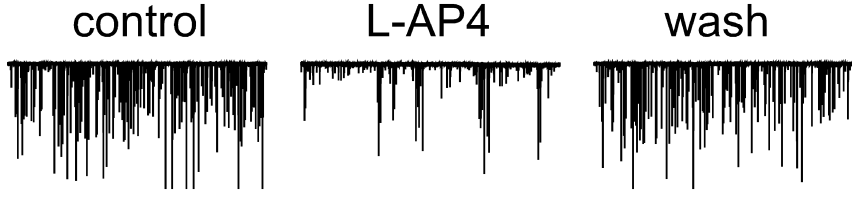

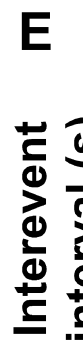
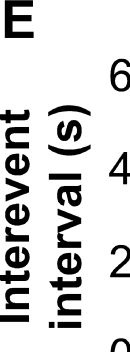

$* *$
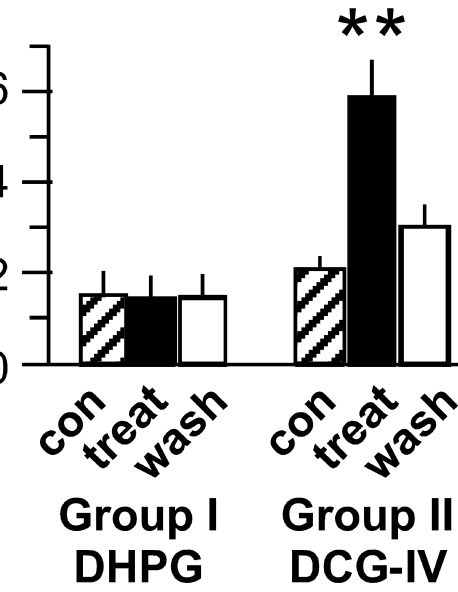

ᄂ
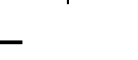

Figure 4. Effects of group-specific mGluR agonists on SPSCs. $A$, Representative sPSC recordings before, during, and after treatment with the group I mGluR agonist DHPG $(50 \mu \mathrm{m})$. $\boldsymbol{B}$, Average sPSC waveforms are similar under control (left) and DHPG (right) conditions. C, D, Representative SPSC recordings before, during, and after treatment with the group II mGluR agonist DCG-IV and the group mGluR agonist L-AP-4, respectively. $E$, Mean \pm SEM change in interevent interval from control (con) values for each group antagonist. ${ }^{* *} p<0.001 ;{ }^{*} p<$ 0.05. treat, Treated; wash, washout.

trol sPSC frequency in a cell. Specifically, antagonists had less effect in cells in which PSC frequency was high (Fig. 6A), whereas a marked increase in frequency (reduction in interval) was evident in cells receiving an initially low frequency of GABAergic transmission (Fig. 6B). This is further illustrated by the plot of the interevent interval in all cells tested with mGluR antagonists before, during, and after treatment (Fig. 6C,D) and by regression analysis of initial interevent interval versus percentage change in interval $(p<0.005$; regression analysis, $r=0.65$ ) (Fig. $6 E$ ). Together, these results suggest endogenous activation of mGluRs plays a key role in regulating GABA transmission to GnRH neurons. The frequency dependence of this response suggests that when PSC frequency is high, there is little endogenous activation of mGluRs, whereas when frequency is low, there is endogenous activation of mGluRs.
mGluR modulation alters the activity of GnRH neurons GnRH neurons display complex rhythmic patterns of firing activity and secretion. To investigate the role of mGluR activation on the activity of GnRH neurons, targeted loose-patch extracellular recordings were made of firing rate before, during, and after treatment with mGluR agonists or antagonists. This method has the advantage of looking at the integrated activity of the GnRH neuron in its network but the disadvantage of a greater probability that the effects observed in the cell of interest are multisynaptic, because no transmitter receptor antagonists are present. Nonetheless, this method can provide insight into the functional consequence of mGluR activation on the activity of GnRH neurons.

Firing frequency was decreased by the broad-spectrum mGluR agonist ACPD $(50 \mu \mathrm{M})$ from $0.8 \pm 0.3 \mathrm{~Hz}$ during the control period to $0.2 \pm 0.1 \mathrm{~Hz}$ during treatment $(n=12 ; p<$ 0.03 ). Figure $7 A$ shows a representative example, and Figure $7 C$ illustrates the percentage change from control; the latter reveals the direction of change in firing while normalizing for different initial firing rates. In contrast, blockade of endogenous activation of mGluRs with a combination of MCPG (1 mM) and CPPG (200 $\mu \mathrm{M})$, a specific group III antagonist, increased firing rate from $0.3 \pm 0.1 \mathrm{~Hz}$ during the control period to $0.7-0.3 \mathrm{~Hz}$ during treatment $(n=15 ; p<0.03)$. Figure $7 B$ shows a representative example, and Figure $7 D$ illustrates the percentage change from control. These data suggest that through modulating GABA drive to $\mathrm{GnRH}$ neurons and perhaps other network effects, endogenous activation of mGluRs changes the firing rate of these cells.

An interesting question arising from the combination of this notion and the frequency dependence of the effect of mGluR antagonists on the interval between GABAergic PSCs is whether the change in firing rate observed in extracellular recordings is dependent on the initial frequency. To test this, the fold difference from control was compared between groups of cells with initial firing frequencies above versus below the median. ACPD induced a $64 \pm 10 \%$ decrease in firing rate in cells below the median, which is similar to the $87 \pm$ $6 \%$ decrease in cells above the median. In contrast, mGluR antagonist treatment induced a $13 \pm 7$-fold increase in firing rate in cells below the median, whereas the decrease was only $3 \pm 1$-fold in cells above the median. With regard to antagonist treatment, the bias toward more stimulation in low-firing-frequency cells may be in part because of greater endogenous activation of mGluRs in the GABA neurons afferent to those cells leading to reduced GABAergic transmission. Likewise, in high-firing-frequency cells, if endogenous mGluR activation is low, antagonism of these receptors would be expected to have a smaller effect.

Another question that arises from the extracellular recording experiments is whether the changes in firing rate observed are caused by mGluR agonist and antagonist effects on presynaptic glutamatergic neurons. To test this, we repeated these studies in the presence of the ionotropic glutamatergic receptor (iGluR) blockers APV and CNQX. The mGluR agonist ACPD $(50 \mu \mathrm{M})$ still significantly inhibited GnRH neuron firing rate from $0.46 \pm$ $0.12 \mathrm{~Hz}$ during the control period to $0.11 \pm 0.05 \mathrm{~Hz}$ during treatment $(n=7 ; p<0.001)$ (percentage change shown in Fig. $7 E$ ). Because iGluR activation was blocked throughout the recording, these data indicated the decrease in firing rate induced by ACPD is not caused by a removal of excitatory glutamatergic transmission. Likewise, the mGluR antagonists MCPG plus CPPG still increased GnRH neuron firing after iGluR blockade, from $0.09 \pm 0.03 \mathrm{~Hz}$ during the control period to $0.42 \pm 0.14 \mathrm{~Hz}$ during treatment $(n=10 ; p<0.01)$ (percentage change shown in Fig. $7 F$ ). Thus, the stimulation in firing rate was not attributable to an increase in iGluR-mediated transmission. 
A Group II and III

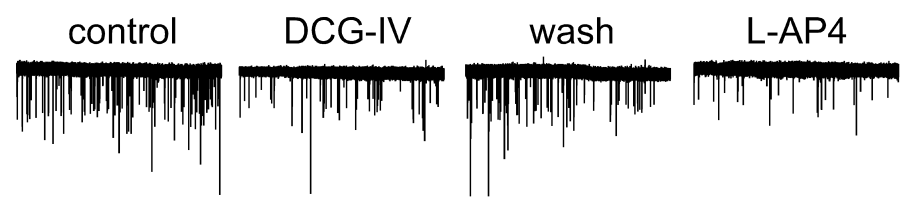

B Only Group II
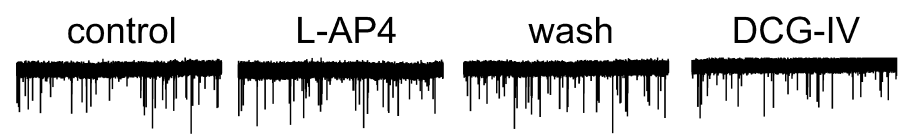

Figure 5. Responsiveness to $\mathrm{mGluR} \mathrm{group} \mathrm{II} \mathrm{only} \mathrm{versus} \mathrm{group} \mathrm{II} \mathrm{and} \mathrm{III} \mathrm{defines} \mathrm{separate} \mathrm{populations} \mathrm{of} \mathrm{GABAergic} \mathrm{afferents} \mathrm{to}$ $\mathrm{GnRH}$ neurons. $A, B$, Representative PSC traces from GnRH neurons in which the frequency of GABAergic PSCs was altered by both group II and III mGluR agonists $(\boldsymbol{A})$ and by only group II agonists $(\boldsymbol{B})$. wash, Washout.

A control

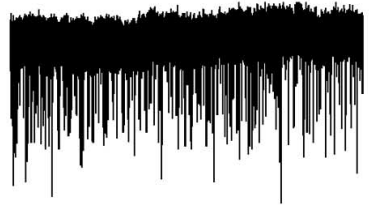

B

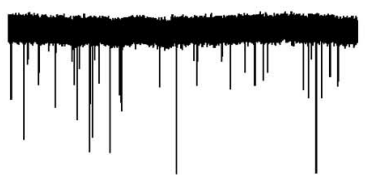

C

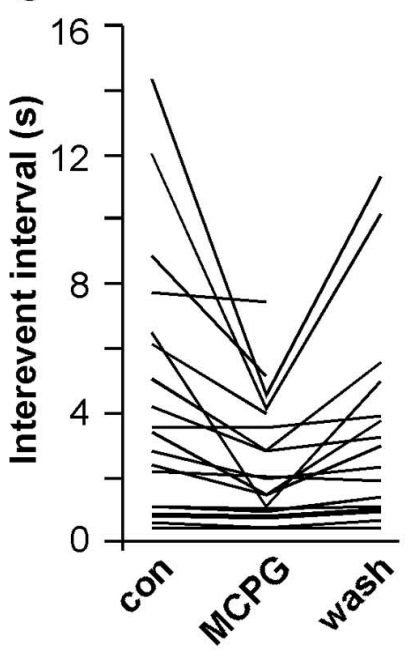

MCPG

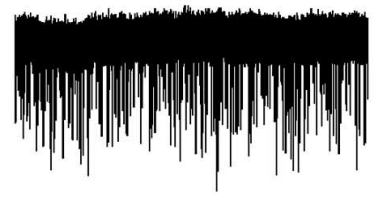

MCPG

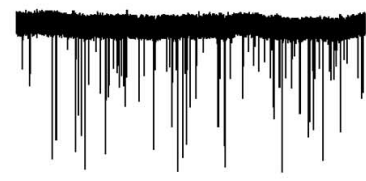

E

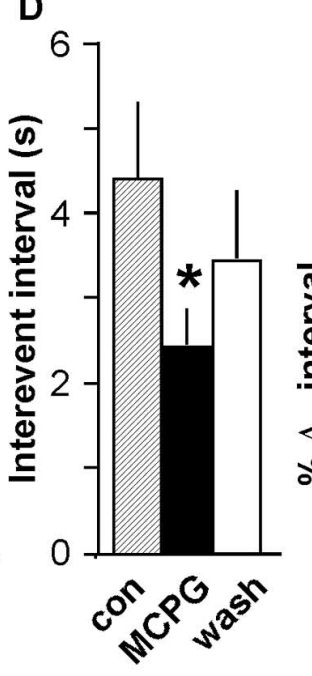

6 wash

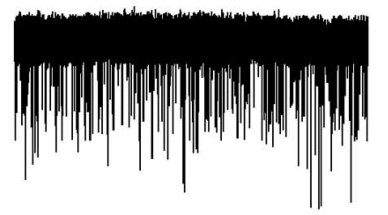

wash

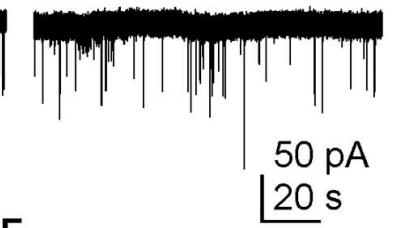

initial interval (s)

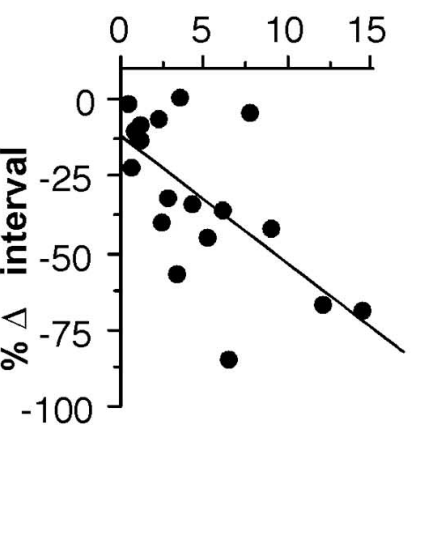

Figure 6. Endogenous activation of mGluRs affects spontaneous PSCs in GnRH neurons. $A, B$, Representative recordings of sPSCs in response to the broad-spectrum mGluR antagonist MCPG from GnRH neurons in which sPSC frequency was initially high $(\boldsymbol{A})$ and low $(\boldsymbol{B})$. C, Plot of interevent interval before, during, and after MCPG treatment, showing that the effect of mGluR antagonism to decrease interevent interval was greatest in cells in which the initial interval was greatest (frequency lowest). D, Mean \pm SEM interevent interval during different phases of treatment. $\boldsymbol{E}$, Correlation between initial interevent interval and percentage change after MCPG treatment $(r=0.65$; $p<0.01$ ). ${ }^{*} p<0.01$ versus control; $p<0.05$ versus washout. con, Control; wash, washout.

Activation of GnRH neurons alters PSC frequency in an mGluR-dependent manner

The recent report that GnRH neurons express VGLUT2 (Hrabovszky et al., 2004) prompted us to ask whether GnRH neurons might serve as a source for the glutamate that activates

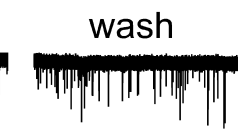

mGluRs on their afferents. As an initial test of this hypothesis, sPSCs were recorded in a $\mathrm{GnRH}$ neuron for a $60 \mathrm{~s}$ control period. Then the GnRH neuron was depolarized 20 times over $1 \mathrm{~s}$ to $+20 \mathrm{mV}$ for $2 \mathrm{~ms} \mathrm{du}$ ration to simulate firing activity (Fig. $8 \mathrm{~A}$, top) and sPSCs recorded for another $60 \mathrm{~s}$. These studies were done under control conditions ( $n=29$ cells) (Fig. $8 A, B)$ and in the presence of mGluR antagonists MCPG plus CPPG ( $n=11$ cells) (Fig. $8 C, D)$. After the simulated firing activity, PSC frequency was suppressed $(p<$ 0.0001 ) (Fig. $8 E, F$ ) for $\sim 10-15 \mathrm{~s}$ in control neurons. This suppression was reduced in the presence of the mGluR antagonists MCPG plus CPPG. In contrast, neither a GnRH receptor antagonist [(DpGlu $^{1}$,D-Phe ${ }^{2}$, D-Trp $\left.{ }^{3,6}\right)-G n R H ; 5 \mu \mathrm{M}$; $n=13$; Bachem, Torrance, CA] nor a galanin receptor antagonist (galantide; 100 nM; $n=14$ ) blocked the stimulationinduced decrease in PSC frequency, indicating that this effect is more likely mediated by glutamate rather than $\mathrm{GnRH}$ or galanin release from $\mathrm{GnRH}$ neurons (Fig. $8 F$ ). Note that mean PSC frequency was not affected in this study, which initially appears in contrast with the data in Figure 6 . It should be noted, however, that because our hypothesis was that activation of GnRH neurons would depress PSC frequency, the majority of cells tested had a higher initial frequency. These were the cells with the least response to MCPG plus CPPG with regard to frequency. These data thus suggest GnRH neural activity initiates a local feedback circuit that uses mGluRs to regulate the activity of GABA neurons afferent to that GnRH neuron.

As an initial test of the composition of this feedback circuit, we repeated the above experiment in the presence of TTX to block sodium-dependent action potentials $(n=$ 21). Under these conditions, simulated firing in GnRH neurons no longer caused a suppression in the activity of the presynaptic GABA neuron (Fig. 8F). This may indicated that an interneuron lies between the output of the GnRH neuron and the GABA afferent or that a TTX-sensitive, sodium-dependent release or response mechanism exists in the $\mathrm{GnRH}$ neuron or GABA afferent, respectively. A potential caveat to this experiment, however, is that the initial frequency of $\mathrm{mP}$ SCs was reduced compared with sPSCs. This may make suppression more difficult to reveal. and we thus interpret these results as only a preliminary indication.

\section{Discussion}

GABA acts via $\mathrm{GABA}_{\mathrm{A}}$ receptors on $\mathrm{GnRH}$ neurons to regulate reproduction (Jarry et al., 1988; Kasuya et al., 1999; Sim et al., 
2000; Bilger et al., 2001; Sullivan et al., 2003; Sullivan and Moenter, 2004a,b, 2005). Here, we demonstrate glutamatergic neuromodulation of both GABAergic transmission to, and the firing rate of, GnRH neurons. These effects occur presynaptically through group II/III mGluRs and are mimicked by GnRH neural activity, suggesting a role for mGluRs in a feedback circuit.

mGluRs modulate neurotransmission, acting presynaptically to reduce transmission at glutamatergic and GABAergic synapses (Glaum and Miller, 1993; Liu et al., 1993; Schoepp and Conn, 1993; Desai et al., 1994; McBain et al., 1994; Chu and Hablitz, 1998; van Hooft et al., 2000). In other brain regions, excitatory glutamate effects may be in part attributable to a concomitant reduction in inhibitory GABAergic drive through this mechanism. In $\mathrm{GnRH}$ neurons, this may not be the case. Although an area of ongoing investigation (Han et al., 2002, 2004; Moenter et al., 2004), evidence suggests GnRH neurons maintain elevated chloride concentrations (DeFazio et al., 2002), placing them in a subcategory of neurons that are depolarized by $\mathrm{GABA}_{\mathrm{A}}$ receptor activation in adulthood (Gallagher et al., 1983; Miller and Dacheux, 1983; Kurahashi and Yau, 1993; Lowe and Gold, 1993; Rohrbough and Spitzer, 1996; Gulledge and Stuart, 2003). Consistent with this, GABAergic transmission to GnRH neurons and responsiveness of these neurons to GABA is directly, not inversely, correlated with reproductive measures (Bilger et al., 2001; Sullivan et al., 2003; Sullivan and Moenter, 2004a,b, 2005). The present results extend these observations. Specifically, mGluR activation inhibited, whereas mGluR antagonism increased, GABAergic transmission to GnRH neurons. In extracellular recordings, which maintain normal intracellular chloride milieu and thus response to GABA, mGluR activation reduced GnRH neuron firing, whereas antagonism stimulated firing. In this study, multisynaptic network effects could account for observed changes. In this regard, blocking iGluRs had no effect on the response to mGluR manipulation in extracellular studies, indicating effects were not secondary to changes in fast glutamatergic transmission. Because firing rate is correlated with release of $\mathrm{GnRH}$ and other neurohormones (Dutton and Dyball, 1979; Nunemaker et al., 2001), these data suggest activation of mGluRs inhibits hormone release, as it did GABAergic transmission.

The present results define one role for glutamatergic action in the GnRH neurosecretory system. Although GnRH neurons express both AMPA- and NMDA-type iGluRs (Brann and Mahesh, 1997; Gore, 2001) and produce currents in response to agonist (Spergel et al., 1999; Kuehl-Kovarik et al., 2002), functional glutamatergic inputs to GnRH neurons have not been well studied directly at the GnRH neuron. Whole-animal and tissue-explant studies demonstrated stimulation or antagonism of iGluRs changed GnRH neuron activity monitored via cFos or release of GnRH or downstream pituitary hormones (Ebling et al., 1990;
Lee et al., 1993; Brann and Mahesh, 1997; Gore, 2001; Ottem et al., 2002). Despite limitations in identifying specific sites of action for glutamate agonists/antagonists, these studies indicate a stimulatory role for iGluRs in reproduction. The present results suggest a novel role for mGluRs: to inhibit GABAergic transmission directly to GnRH neurons. Because of the dominance of GABAergic contacts and synaptic transmission to these neurons (Sim et al., 2000; Jansen et al., 2003; Sullivan et al., 2003), mGluRs may substantially impact GnRH neuron activity.

There are several sources of glutamate for endogenous activation of these receptors. First, there may be glutamatergic innervation of the presynaptic GABA neuron. Second, glutamatergic stimulation of the postsynaptic GnRH neuron may allow transmitter diffusion that could activate presynaptic mGluRs. This so-called "spillover" provides a mechanism for cross talk and integration between nearby synapses (Scanziani et al., 1997; Vizi and Kiss, 1998; Mitchell and Silver, 2000; Semyanov and Kullmann, 2000). Such heterosynaptic depression is evident in the hippocampus and is abolished by mGluR antagonists (Scanziani et al., 1997). Third, the presynaptic GABA neuron itself may be glutamatergic. Although not released by most GABAergic terminals (Somogyi et al., 1986), glutamate is a precursor for GABA synthesis. In some cases, both GABA and glutamate are stored by the same terminals (Sandler and Smith, 1991; Somogyi, 2002; Ottem et al., 2004) and may be coreleased. Finally, postsynaptic dendrites may release glutamate or other transmitters specifically to the presynaptic terminals (Zilberter, 2000). 

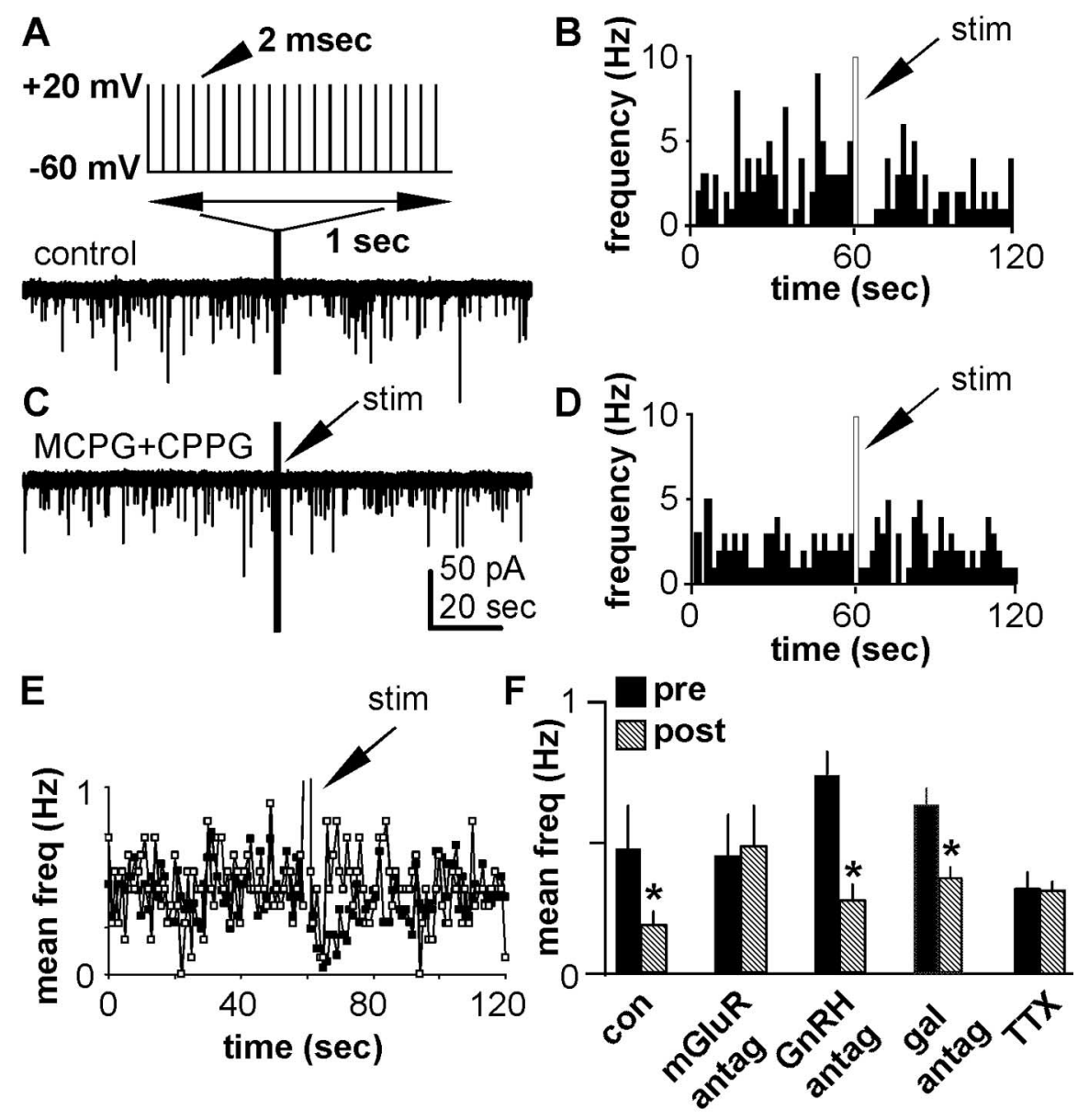

Figure 8. GnRH neurons provide feedback regulation of GABAergic PSC frequency via mGluRs. $A$, sPSCs recorded before and after 20 depolarizing pulses ( $\boldsymbol{A}$, inset; arrow marked "stim" in remainder of figure). $\boldsymbol{B}$, Histogram showing frequency of PSCs from the cell in $\boldsymbol{A}$ binned at 1 sintervals. $\boldsymbol{C}, \boldsymbol{D}$, As in $\boldsymbol{A}$ and $\boldsymbol{B}$, respectively, but in the presence of MCPG plus CPPG. $\boldsymbol{E}$, Average frequency (freq) of sPSCs from all cells recorded. Filled symbols are control, and open symbols are MCPG plus CPPG. $F$, Average sPSC frequency (freq) during the $10 \mathrm{~s}$ before the stimulation (black bars) versus the $10 \mathrm{~s}$ after the stimulation (hatched bars) under control conditions (con; $n=29$ ) and with bath presence of MCPG plus CPG (mGluR antag; $n=11)$, GnRH antagonist [GnRH antag; (D-pGlu ${ }^{1}, \mathrm{D}-\mathrm{Phe}^{2}, \mathrm{D}$-Trp $\left.{ }^{3,6}\right)-\mathrm{GnRH} ; n=13$, galantide (gal antag; $\left.n=14\right)$, or $\operatorname{TTX}(n=21) .{ }^{*} p<0.0001$; paired $t$ test versus control prestimulus values. Error bars represent SEM.

This latter mechanism, or a reciprocal axonic connection, is interesting, because most GnRH neurons express VGLUT2 (Hrabovszky et al., 2004). GnRH neurons are thus poised to release glutamate, regulating local transmitter milieu and thereby GABAergic transmission to themselves. Supporting this, simulation of firing in GnRH neurons reduced GABAergic PSC frequency in an mGluR-dependent manner, whereas blocking galanin or GnRH receptors did not alter this response. The latter is consistent with previous observations that few non-GnRH neurons in the preoptic area express $\mathrm{GnRH}$ receptors (Xu et al., 2004). This suggests GnRH neurons are either one of many direct sources of glutamate activating presynaptic mGluRs or that they initiate a local feedback circuit that uses mGluRs to inhibit their afferents. The elimination of the feedback by TTX suggests at least one interneuron is involved in this circuitry; however, these data may be confounded by the lower initial frequency of mPSCs, making suppression difficult to reveal.

The involvement GnRH neurons in a local feedback circuit may explain the frequency dependence of the PSC response to mGluR antagonists. When PSC frequency was high, mGluR antagonism had little effect, suggesting low endogenous activation of these receptors. In contrast, when PSC frequency was low, mGluR antagonism increased frequency, suggesting elevated endogenous activation of mGluRs contributes to lowering GABAergic transmission to these cells. GnRH neurons thus present as two populations with regard to PSC frequency and mGluR activity. These may be two functionally distinct populations with regard to afferent response to mGluRs. The consistent inhibition of GABA transmission to these neurons by mGluR activation argues against this.

Alternatively, there may be one population with a component(s) that varies temporally. One such temporal variable may be a cycle of GABAergic transmission. At the time a recording is initiated, a cell may be at any point in that cycle. Those at the peak will have initial high-frequency PSCs, those at the trough, low-frequency PSCs. This suggests a second temporal variable: endogenous variations in glutamatergic milieu that provides set points for GABAergic transmission to $\mathrm{GnRH}$ neurons.

The spontaneous changes in $\mathrm{GnRH}$ neuron firing rate in combination with their glutamatergic phenotype makes them an attractive option for producing a variable local glutamate milieu. The GnRH neural network must operate in an intermittent manner, with hormone release every few minutes to every few hours, for reproduction to proceed. Anterior pituitary function depends on $\mathrm{GnRH}$ release being episodic rather than continuous (Belchetz et al., 1978), and frequency of $\mathrm{GnRH}$ codes for differential secretion of two hormones produced in the target cells (Wildt et al., 1981; Shupnik, 1990). The source of episodic GnRH release is unknown, but evidence suggests the rudiments are within the GnRH neural network. GnRH cell lines produce rhythmic firing, hormone release, gene transcription, and calcium oscillations in the absence of other cell types (Krsmanovic et al., 1992; Martinez de la Escalera et al., 1992; Charles and Hales, 1995; Nunez et al., 1998; Nunemaker et al., 2001; Pitts et al., 2001; VazquezMartinez et al., 2001). Cultured primary GnRH neurons, GnRH neurons in brain slices, and acutely dispersed GnRH neurons, although subject to influences from other cell types, also exhibit spontaneous rhythmic activity (Terasawa et al., 1999; KuehlKovarik et al., 2002; Moore et al., 2002; Nunemaker et al., 2002).

Although the source of the rhythm may be the GnRH neuron, various inputs help synchronize, increase the robustness, and affect the frequency of this rhythm to produce the overall pattern of hormone release. GnRH neurons produce burst rhythms at higher frequency than hormone release (Terasawa et al., 1999; Kuehl-Kovarik et al., 2002; Nunemaker et al., 2003b), suggesting the overall pattern of hormone release requires interactions with other GnRH neurons and/or other cell types (Moenter et al., 2003). GnRH-GABA feedback may occur at this higher-thanhormone-release frequency. Furthermore, a number of factors 
that influence fertility, including photoperiod (Barrell et al., 2000), steroids (Herbison, 1998), nutrition (Schreihofer et al., 1993), and stress (Williams et al., 2001), are not received directly or exclusively by GnRH neurons. Some of these are conveyed, in part, by changes in GABAergic transmission (Sullivan et al., 2003; Sullivan and Moenter, 2004a,b, 2005).

A change in the duration of a cycle of GABAergic transmission could account for and drive such responses. Alternatively, but not exclusively, changes in the GnRH neuron firing pattern in combination with other non-GnRH sources of glutamate input to GABAergic afferents could adjust a GABAergic transmission cycle via mGluR activation. mGluR modulation impacts the overall activity of this neuroendocrine system, as was evidenced in the extracellular recordings in the present study. The demonstration that endogenous activation of presynaptic mGluRs plays a role in setting GABAergic transmission to $\mathrm{GnRH}$ neurons has implications for both the transmission of cues that affect fertility and for generation/modulation of rhythmic GnRH release.

\section{References}

Anwyl R (1999) Metabotropic glutamate receptors: electrophysiological properties and role in plasticity. Brain Res Brain Res Rev 29:83-120.

Barrell GK, Thrun LA, Brown ME, Viguie C, Karsch FJ (2000) Importance of photoperiodic signal quality to entrainment of the circannual reproductive rhythm of the ewe. Biol Reprod 63:769-774.

Barry PH (1994) JPCalc, a software package for calculating liquid junction potential corrections in patch-clamp, intracellular, epithelial and bilayer measurements and for correcting junction potential measurements. J Neurosci Methods 51:107-116.

Belchetz PE, Plant TM, Nakai Y, Keogh EJ, Knobil E (1978) Hypophysial responses to continuous and intermittent delivery of hypopthalamic gonadotropin-releasing hormone. Science 202:631-633.

Bilger M, Heger S, Brann DW, Paredes A, Ojeda SR (2001) A conditional tetracycline-regulated increase in gamma amino butyric acid production near luteinizing hormone-releasing hormone nerve terminals disrupts estrous cyclicity in the rat. Endocrinology 142:2102-2114.

Brann DW, Mahesh VB (1997) Excitatory amino acids: evidence for a role in the control of reproduction and anterior pituitary hormone secretion. Endocr Rev 18:678-700.

Charles AC, Hales TG (1995) Mechanisms of spontaneous calcium oscillations and action potentials in immortalized hypothalamic (GT1-7) neurons. J Neurophysiol 73:56-64.

Chu Z, Hablitz JJ (1998) Activation of group I mGluRs increases spontaneous IPSC frequency in rat frontal cortex. J Neurophysiol 80:621-627.

Conn PJ, Pin JP (1997) Pharmacology and functions of metabotropic glutamate receptors. Annu Rev Pharmacol Toxicol 37:205-237.

DeFazio RA, Heger S, Ojeda SR, Moenter SM (2002) Activation of A-type gamma-aminobutyric acid receptors excites gonadotropin-releasing hormone neurons. Mol Endocrinol 16:2872-2891.

Desai MA, McBain CJ, Kauer JA, Conn PJ (1994) Metabotropic glutamate receptor-induced disinhibition is mediated by reduced transmission at excitatory synapses onto interneurons and inhibitory synapses onto pyramidal cells. Neurosci Lett 181:78-82.

Dutton A, Dyball RE (1979) Phasic firing enhances vasopressin release from the rat neurohypophysis. J Physiol (Lond) 290:433-440.

Dziedzic B, Prevot V, Lomniczi A, Jung H, Cornea A, Ojeda SR (2003) Neuron-to-glia signaling mediated by excitatory amino acid receptors regulates ErbB receptor function in astroglial cells of the neuroendocrine brain. J Neurosci 23:915-926.

Ebling FJ, Wood RI, Karsch FJ, Vannerson LA, Suttie JM, Bucholtz DC, Schall RE, Foster DL (1990) Metabolic interfaces between growth and reproduction. III. Central mechanisms controlling pulsatile luteinizing hormone secretion in the nutritionally growth-limited female lamb. Endocrinology 126:2719-2727.

Gallagher JP, Nakamura J, Shinnick-Gallagher P (1983) The effects of temperature, $\mathrm{pH}$ and $\mathrm{Cl}$-pump inhibitors on GABA responses recorded from cat dorsal root ganglia. Brain Res 267:249-259.

Glaum SR, Miller RJ (1993) Activation of metabotropic glutamate receptors produces reciprocal regulation of ionotropic glutamate and GABA re- sponses in the nucleus of the tractus solitarius of the rat. J Neurosci 13:1636-1641.

Gore AC (2001) Gonadotropin-releasing hormone neurons, NMDA receptors, and their regulation by steroid hormones across the reproductive life cycle. Brain Res Brain Res Rev 37:235-248.

Gulledge AT, Stuart GJ (2003) Excitatory actions of GABA in the cortex. Neuron 37:299-309.

Han SK, Abraham IM, Herbison AE (2002) Effect of GABA on GnRH neurons switches from depolarization to hyperpolarization at puberty in the female mouse. Endocrinology 143:1459-1466.

Han SK, Todman MG, Herbison AE (2004) Endogenous GABA release inhibits the firing of adult gonadotropin-releasing hormone neurons. Endocrinology 145:495-499.

Herbison AE (1998) Multimodal influence of estrogen upon gonadotropinreleasing hormone neurons. Mol Endocrinol 19:302-330.

Hrabovszky E, Turi GF, Kallo I, Liposits Z (2004) Expression of vesicular glutamate transporter-2 in gonadotropin-releasing hormone neurons of the adult male rat. Endocrinology 145:4018-4021.

Jansen HT, Cutter C, Hardy S, Lehman MN, Goodman RL (2003) Seasonal plasticity within the GnRH system of the ewe: changes in identified GnRH inputs and in glial association. Endocrinology 144:3663-3676.

Jarry H, Perschl A, Wuttke W (1988) Further evidence that preoptic anterior hypothalamic GABAergic neurons are part of the GnRH pulse and surge generator. Acta Endocrinol (Copenh) 118:573-579.

Kasuya E, Nyberg CL, Mogi K, Terasawa E (1999) A role of gamma-amino butyric acid (GABA) and glutamate in control of puberty in female rhesus monkeys: effect of an antisense oligodeoxynucleotide for GAD67 messenger ribonucleic acid and MK801 on luteinizing hormone-releasing hormone release. Endocrinology 140:705-712.

Krsmanovic LZ, Stojilkovic SS, Merelli F, Dufour SM, Virmani MA, Catt KJ (1992) Calcium signaling and episodic secretion of gonadotropinreleasing hormone in hypothalamic neurons. Proc Natl Acad Sci USA 89:8462-8466.

Kuehl-Kovarik MC, Pouliot WA, Halterman GL, Handa RJ, Dudek FE, Partin KM (2002) Episodic bursting activity and response to excitatory amino acids in acutely dissociated gonadotropin-releasing hormone neurons genetically targeted with green fluorescent protein. J Neurosci 22:2313-2322.

Kurahashi T, Yau KW (1993) Co-existence of cationic and chloride components in odorant-induced current of vertebrate olfactory receptor cells Nature 363:71-74.

Lee WS, Abbud R, Hoffman GE, Smith MS (1993) Effects of N-methyl-Daspartate receptor activation on cFos expression in luteinizing hormonereleasing hormone neurons in female rats. Endocrinology 133:2248-2254.

Leranth C, MacLusky NJ, Sakamoto H, Shanabrough M, Naftolin F (1985) Glutamic acid decarboxylase-containing axons synapse on LHRH neurons in the rat medial preoptic area. Neuroendocrinology 40:536-539.

Liu YB, Disterhoft JF, Slater NT (1993) Activation of metabotropic glutamate receptors induces long-term depression of GABAergic inhibition in hippocampus. J Neurophysiol 69:1000-1004.

Lowe G, Gold GH (1993) Nonlinear amplification by calcium-dependent chloride channels in olfactory receptor cells. Nature 366:283-286.

Martinez de la Escalera G, Choi AL, Weiner RI (1992) Generation and synchronization of gonadotropin-releasing hormone $(\mathrm{GnRH})$ pulses: intrinsic properties of the GT1-1 GnRH neuronal cell line. Proc Natl Acad Sci USA 89:1852-1855.

McBain CJ, DiChiara TJ, Kauer JA (1994) Activation of metabotropic glutamate receptors differentially affects two classes of hippocampal interneurons and potentiates excitatory synaptic transmission. J Neurosci 14:4433-4445.

Meeker RB, Greenwood RS, Hayward JN (1994) Glutamate receptors in the rat hypothalamus and pituitary. Endocrinology 134:621-629.

Miller RF, Dacheux RF (1983) Intracellular chloride in retinal neurons: measurement and meaning. Vision Res 23:399-411.

Mitchell SJ, Silver RA (2000) Glutamate spillover suppresses inhibition by activating presynaptic mGluRs. Nature 404:498-502.

Moenter SM, DeFazio AR, Pitts GR, Nunemaker CS (2003) Mechanisms underlying episodic gonadotropin-releasing hormone secretion. Front Neuroendocrinol 24:79-93.

Moenter SM, Sullivan SD, DeFazio RA (2004) Endogenous GABA can excite GnRH neurons. Paper presented at the 86th Meeting of The Endocrine Society, New Orleans, LA, June.

Moore Jr JP, Shang E, Wray S (2002) In situ GABAergic modulation of 
synchronous gonadotropin releasing hormone-1 neuronal activity. J Neurosci 22:8932-8941.

Nakanishi S (1992) Molecular diversity of glutamate receptors and implications for brain function. Science 258:597-603.

Nakanishi S (1994) Metabotropic glutamate receptors: synaptic transmission, modulation, and plasticity. Neuron 13:1031-1037.

Nunemaker CS, DeFazio RA, Geusz ME, Herzog ED, Pitts GR, Moenter SM (2001) Long-term recordings of networks of immortalized GnRH neurons reveal episodic patterns of electrical activity. J Neurophysiol 86:86-93.

Nunemaker CS, DeFazio RA, Moenter SM (2002) Estradiol-sensitive afferents modulate long-term episodic firing patterns of GnRH neurons. Endocrinology 143:2284-2292.

Nunemaker CS, DeFazio RA, Moenter SM (2003a) A targeted extracellular approach for recording long-term firing patterns of excitable cells: a practical guide. Biol Proced Online 5:53-62.

Nunemaker CS, Straume M, DeFazio RA, Moenter SM (2003b) Gonadotropin-releasing hormone neurons generate interacting rhythms in multiple time domains. Endocrinology 144:823-831.

Nunez L, Faught WJ, Frawley LS (1998) Episodic gonadotropin-releasing hormone gene expression revealed by dynamic monitoring of luciferase reporter activity in single, living neurons. Proc Natl Acad Sci USA 95:9648-9653.

Ottem EN, Godwin JG, Petersen SL (2002) Glutamatergic signaling through the $N$-methyl-D-aspartate receptor directly activates medial subpopulations of luteinizing hormone-releasing hormone (LHRH) neurons, but does not appear to mediate the effects of estradiol on LHRH gene expression. Endocrinology 143:4837-4845.

Ottem EN, Godwin JG, Krishnan S, Petersen SL (2004) Dual-phenotype GABA/glutamate neurons in adult preoptic area: sexual dimorphism and function. J Neurosci 24:8097-8105.

Pitts GR, Nunemaker CS, Moenter SM (2001) Cycles of transcription and translation do not comprise the gonadotropin-releasing hormone pulse generator in GT1 cells. Endocrinology 142:1858-1864.

Pompolo S, Pereira A, Kaneko T, Clarke IJ (2003) Seasonal changes in the inputs to gonadotropin-releasing hormone neurones in the ewe brain: an assessment by conventional fluorescence and confocal microscopy. J Neuroendocrinol 15:538-545.

Rohrbough J, Spitzer NC (1996) Regulation of intracellular $\mathrm{Cl}^{-}$levels by $\mathrm{Na}^{+}$-dependent $\mathrm{Cl}^{-}$cotransport distinguishes depolarizing from hyperpolarizing $\mathrm{GABA}_{\mathrm{A}}$ receptor-mediated responses in spinal neurons. J Neurosci 16:82-91.

Sandler R, Smith AD (1991) Coexistence of GABA and glutamate in mossy fiber terminals of the primate hippocampus: an ultrastructural study. J Comp Neurol 303:177-192.

Scanziani M, Salin PA, Vogt KE, Malenka RC, Nicoll RA (1997) Usedependent increases in glutamate concentration activate presynaptic metabotropic glutamate receptors. Nature 385:630-634.

Schoepp DD, Conn PJ (1993) Metabotropic glutamate receptors in brain function and pathology. Trends Pharmacol Sci 14:13-20.

Schrader LA, Tasker JG (1997) Presynaptic modulation by metabotropic glutamate receptors of excitatory and inhibitory synaptic inputs to hypothalamic magnocellular neurons. J Neurophysiol 77:527-536.

Schreihofer DA, Parfitt DB, Cameron JL (1993) Suppression of luteinizing hormone secretion during short-term fasting in male rhesus monkeys: the role of metabolic versus stress signals. Endocrinology 132:1881-1889.

Semyanov A, Kullmann DM (2000) Modulation of GABAergic signaling among interneurons by metabotropic glutamate receptors. Neuron 25:663-672.

Shupnik MA (1990) Effects of gonadotropin-releasing hormone on rat gonadotropin gene transcription in vitro: requirement for pulsatile administration for luteinizing hormone-beta gene stimulation. Mol Endocrinol 4:1444-1450.

Sim JA, Skynner MJ, Pape JR, Herbison AE (2000) Late postnatal reorganization of $\mathrm{GABA}(\mathrm{A})$ receptor signaling in native $\mathrm{GnRH}$ neurons. Eur J Neurosci 12:3497-3504.

Somogyi J (2002) Differences in ratios of GABA, glycine and glutamate im- munoreactivities in nerve terminals on rat hindlimb motoneurons: a possible source of post-synaptic variability. Brain Res Bull 59:151-161.

Somogyi P, Halasy K, Somogyi J, Storm-Mathisen J, Ottersen OP (1986) Quantification of immunogold labelling reveals enrichment of glutamate in mossy and parallel fibre terminals in cat cerebellum. Neuroscience 19:1045-1050.

Sortino MA, Aleppo G, Copani A, Casabona G, Nicoletti F, Ventra C, Kuhn R, Knopfel T, Malitschek B, Canonico PL (1996) Immortalized hypothalamic neurons express metabotropic glutamate receptors positively coupled to cyclic AMP formation. Eur J Neurosci 8:2407-2415.

Spergel DJ, Kruth U, Hanley DF, Sprengel R, Seeburg PH (1999) GABAand glutamate-activated channels in green fluorescent protein-tagged gonadotropin-releasing hormone neurons in transgenic mice. J Neurosci 19:2037-2050.

Sullivan SD, Moenter SM (2003) Neurosteroids alter gamma-aminobutyric acid postsynaptic currents in gonadotropin-releasing hormone neurons: a possible mechanism for direct steroidal control. Endocrinology 144:4366-4375.

Sullivan SD, Moenter SM (2004a) Gamma-aminobutyric acid neurons integrate and rapidly transmit permissive and inhibitory metabolic cues to gonadotropin-releasing hormone neurons. Endocrinology 145:1194-1202.

Sullivan SD, Moenter SM (2004b) Prenatal androgens alter GABAergic drive to gonadotropin-releasing hormone neurons: implications for a common fertility disorder. Proc Natl Acad Sci USA 101:7129-7134.

Sullivan SD, Moenter SM (2005) GABAergic integration of progesterone and androgen feedback to gonadotropin-releasing hormone neurons. Biol Reprod 72:33-41.

Sullivan SD, DeFazio RA, Moenter SM (2003) Metabolic regulation of fertility through presynaptic and postsynaptic signaling to gonadotropinreleasing hormone neurons. J Neurosci 23:8578-8585.

Suter KJ, Wuarin JP, Smith BN, Dudek FE, Moenter SM (2000) Whole-cell recordings from preoptic/hypothalamic slices reveal burst firing in gonadotropin-releasing hormone neurons identified with green fluorescent protein in transgenic mice. Endocrinology 141:3731-3736.

Terasawa E, Schanhofer WK, Keen KL, Luchansky L (1999) Intracellular $\mathrm{Ca}^{2+}$ oscillations in luteinizing hormone-releasing hormone neurons derived from the embryonic olfactory placode of the rhesus monkey. J Neurosci 19:5898-5909.

van den Pol AN, Gao XB, Patrylo PR, Ghosh PK, Obrietan K (1998) Glutamate inhibits GABA excitatory activity in developing neurons. J Neurosci 18:10749-10761.

van Hooft JA, Giuffrida R, Blatow M, Monyer H (2000) Differential expression of group I metabotropic glutamate receptors in functionally distinct hippocampal interneurons. J Neurosci 20:3544-3551.

Vazquez-Martinez R, Shorte SL, Boockfor FR, Frawley LS (2001) Synchronized exocytotic bursts from gonadotropin-releasing hormoneexpressing cells: dual control by intrinsic cellular pulsatility and gap junctional communication. Endocrinology 142:2095-2101.

Vizi ES, Kiss JP (1998) Neurochemistry and pharmacology of the major hippocampal transmitter systems: synaptic and nonsynaptic interactions. Hippocampus 8:566-607.

Wildt L, Hausler A, Marshall G, Hutchison JS, Plant TM, Belchetz PE, Knobil E (1981) Frequency and amplitude of gonadotropin-releasing hormone stimulation and gonadotropin secretion in the rhesus monkey. Endocrinology 109:376-385.

Williams NI, Caston-Balderrama AL, Helmreich DL, Parfitt DB, Nosbisch C, Cameron JL (2001) Longitudinal changes in reproductive hormones and menstrual cyclicity in cynomolgus monkeys during strenuous exercise training: abrupt transition to exercise-induced amenorrhea. Endocrinology 142:2381-2389.

Xu C, Xu X-Z, Nunemaker CS, Moenter SM (2004) Dose-dependent switch in response of gonadotropin-releasing hormone $(\mathrm{GnRH})$ neurons to GnRH mediated through the type I GnRH receptor. Endocrinology 145:728-735.

Zilberter Y (2000) Dendritic release of glutamate suppresses synaptic inhibition of pyramidal neurons in rat neocortex. J Physiol (Lond) 528:489-496. 